Ardeer; chief rosearch engineer, G. and J. Weir, Ltd.; assistant director of research, Gas Research Board; director of research, Federated Foundries, Ltd.; chief research engineer, John Brown Land Boilers, Ltd., before returning to $G$. and J. Weir, Ltd., to form a Development Division in 1956.

Dr. Silver has published a large number of research papers on mechanical engineering, combustion engineering and physics, and has contributed to discussions on the education and training of engineers and applied sciontists. Among the major engineering achievoments to his credit have been designs for large boiler plant for the North of Scotland Hydro-Electric Board, the South of Scotland Electricity Board and the Central Electricity Generating Board. Dr. Silver is regarded as a world authority on the desalination of sea water and has just returned from an international conference on this subject held in Athens. $\mathrm{He}$ designed and was responsible not only for the pilot plant but also for the actual installation of 'Multiflash' sea-water distillation plants at Guernsey and Kuwait in 1960 , providing respectively 500,000 and $1,000,000$ gallons a day of fresh water from sea-water.

Agriculture in the Ahmadu Bello University, Northern Nigeria: Prof. H. S. Darling

Dr. H. S. DarLing has been appointed professor and dean of agriculture and director of the Samaru Institute for Agricultural Research at the Ahmadu Bollo University, Zaria, Northern Nigeria. Dr. Darling was born in Northern Ireland, where he was oducated at Watt's Endowed School, Lurgan, at Greenmount Agricultural Colloge and at The Queon's University of Belfast. Graduating with first-class honours in zoology and agricultural zoology in 1938 and 1939 respectively, he went to Trinidad in 1940 , where he worked on cacao thrips and gained the associateship of the Imperial College of Tropical Agriculture in 1942. After an interlude on pest infestation work with the Ministry of Food in 1942-43, he joined the Middle East Anti-Locust Unit, in which he served in Persia and Arabia during 1943-44. He then worked as ontomologist in the Research Division of the Uganda Department of Agriculture until 1947, when he transferred to a similar post in the Sudan, where he worked mainly on cotton pests. In 1949 he was appointed senior lecturer in agrieultural zoology in the University College of Khartoum (now University of Khartoum), where he carried out research on tho pests of stored grain. In 1954 he took up the post of head of the Department of Hop Research in Wye College (University of London), where he held the rank of senior principal scientific officer.

\section{The Keele Experiment}

IT is now more than a decade since the then University College of North Staffordshire reccived its first undergraduates into its Foundation Year Course. There have been many references to this part of 'the Koole experiment', but thore has, so far, beon little factual evidonco to show to what extent the new types of courses introducod in the first year at Keolo have succooded in their object. In order to provide for a proper invostigation of this question, the College last year sought financial support from the Nuffield Foundation. The appointment is now announced in the University of Keele of A. H. Iliffe, lecturer in the Department of Psychology, as a Resoarch Fellow supported by the Nuffield Foundation's grant to conduct an investigation over the coming two years into the structure, offect and effectivoness of the
Foundation Year Course and influences on the performance of undergraduates during this year. It is hoped that relationships between the Foundation Year and subsequent performance may also be traced.

\section{The Association for Tropical Biology}

A conference on "Neotropical Botany" was held at the Imperial College of Tropical Agriculture, Trinidad, which is the Agricultural Faculty of the University of the West Indies, during July 1-7. The National Science Foundation, Washington, provided a grant which enabled thirty invited delegates from Latin Amorica, the United States, Holland and the Caribbean to attend. The purpose of the conference was to survey the major gaps in present-day knowledge of the various botanical disciplines in the Now World Tropics, and to suggest ways and means by which the position might be improved, not only in providing facilities for research, but also for teaching and training. It became apparent that the field should not be limited to neotropical botany alone, but that consideration must be given to the study of tropical biology as a whole, more particularly in view of the findings of the conference on "Problems in Education and Research in Tropical Biology" held at the Universidad de Costa Rica, San José, during April 23-27. To further this aim, the Trinidad Conference constituted the Association for Tropical Biology, the purpose and function of which would be: (1) to stimulate, encourage and support research in tropical biology; (2) to stimulate the training and interchange of students, teachers and investigators in this field; (3) the development of facilities to attain these objects.

A small working committee was appointed consisting of: J. W. Purseglove, professor of botany, University of the West Indies, Trinidad (chairman); Tobias Lasser, director, Instituto Botánico, Universidad Central, Caracas, Venezuela; Bassett Maguire, head curator, New York Botanical Garden, New York. The following alternates were also elected: C. D. Adams, senior lecturer, Department of Botany, University of the West Indies, Jamaica; A. Fernán. dez-Pérez, director, Department of Botany, Universidad Nacional do Colombia, Instituto de Ciencias Naturales, Bogotá; S. A. Cain, Charles Lathrop Pack professor of conservation, School of Natural Rosources, University of Michigan, Ann Arbor. Further information and details concorning membership of the new Association can be obtained from Prof. J. W. Purseglove, Imperial College of Tropical Agriculture, St. Augustine, Trinidad, West Indies.

\section{National Museums of Southern Rhodesia}

$\mathrm{IT}_{\mathrm{T}}$ is seldom that a director can in a single annual report refer to a building programme involving three new museums situated some 500 milos apart. This, however, has happened in Southern Rhodesia, and in the annual report for $1961, \mathrm{Mr}$. R. H. N. Smithers (director of the National Museums of Southern Rhodesia) refers to the progress of the planning and erecting of new buildings at Bulawayo, Salisbury and Umtali (Pp. 26. Causoway, S. Rhodesia: National Musoums of Southern Rhodesia, 1962). In Bulawayo and Umtali it is anticipated that the buildings will be completed in the autumn of 1962 , and in Salisbury during the early part of 1963 . The buildings have been designed by local architects with the full co-operation of the museum staffs. In spite of the many demands for continual advice in the building projects, it is significant that the staff have 